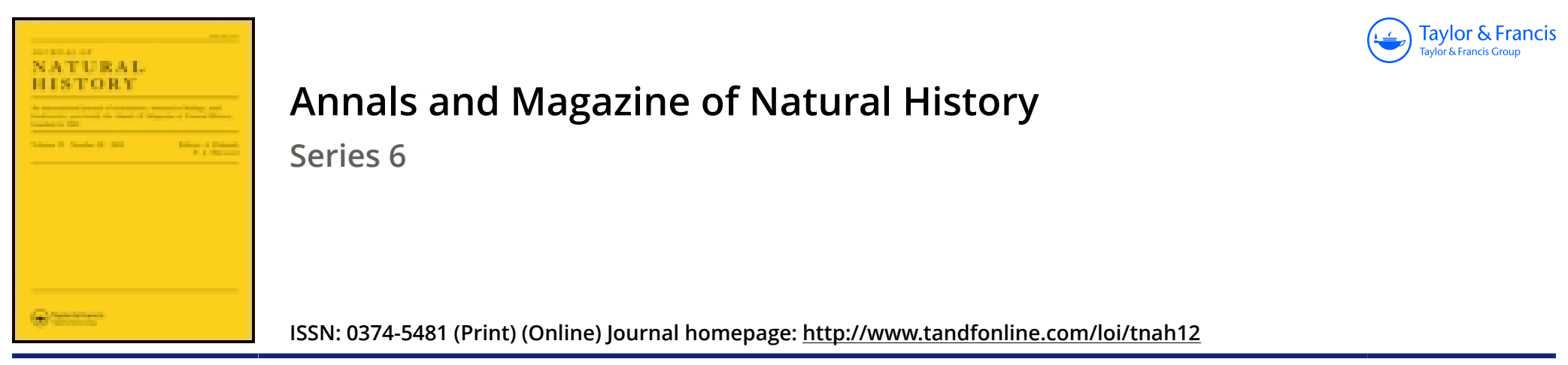

\title{
On Nephromyces, a new genus of Fungi parasitic in the kidney of the Molgulidæ
}

\section{M.A. Giard}

To cite this article: M.A. Giard (1888) On Nephromyces, a new genus of Fungi parasitic in the kidney of the Molgulidæ, Annals and Magazine of Natural History, 1:5, 386-388, DOI: 10.1080/00222938809460753

To link to this article: http://dx.doi.org/10.1080/00222938809460753

册 Published online: 12 Oct 2009.

Submit your article to this journal $\sqsubset \pi$

Џll Article views: 3

Q View related articles $₫$ 
twenty-three to thirty-one; among the individuals (all of large size) in which the phenomenon was not observed the number of arms raried from thirty-nine to forty-two. The great number of arms in old individuals thus seems to be connected with this formation of intercalary arms. I have recognized some indications of an analogous formation in Heliaster. In connexion with this $\mathbf{I}$ will remark that, in Brisinga mediterranea, the nine arms are entirely formed before the close of the larval period; young examples of Solaster and Acanthaster did not present any arms in course of formation.

In order to classify the starfishes of the sea around Cape Horn I have had to form the new genera Diplastinas, Asteroderma, Poraniopsis, Cribraster, Lebrunaster, and Asterodon. In the genus Diplastinas I range Asterias-forms which have at least two rows of adambulacral spines ; Asteroderma includes Asterioe without any apparent spines or pedicellarie, and in which the dorsal skeleton is almost deficient. The genus Poraniopsis presents characters exactly intermediate between those of Echinaster and Porania; the animals of this genus have the ventral surface differentiated from the dorsal surface and thick integuments, like the Porania, while the very short arms are rounded and covered with spines. The Cribrasteres are Cribrellos having paxilli upon the ventral surface; in Lebrunaster marginal plates begin to be differentiated. These animals form the passage towards the Ganerice, which themselves lead to the Cycethre. The species of Asterodon, previously elassed with the Goniasteridæ, are in reality Archasteridæ. They are characterized by their dentary plates, each having a hyaline spine laid down upon them with its point directed outwards; these two spines may unite and form only a single hyaline interradial spine, resembling the dentary plume of the sea-urchins. Asterodon has also at the angle of the arms an unpaired marginal plate, and the ventral spines often group themselves into multifid pedicellariæ, as in Pectinaster, E. P. To this genus must be referred Astrogonium singulare, Müll. \& Tr., A. meridionalis, Smith, Pentagonaster Belli, Studer, Calliderma Grayi, Bell, and two new species, Asterodon pedicellaris and granulosus._Comptes Rendus, March 12, 1888, p. 763 .

On Nephromyces, a new Genus of Fungi parasitic in the Kidney of the Molgulidæ. By M. A. Giard.

In a fine memoir on Cyclostoma elegans, M. Garnault* has recently noticed the existence in this mollusk of a closed organ (glande à concrétions of Claparède) which contains at the same time uric products and symbiotic bacilli. Several years ago I observed phenomena of symbiosis of the same kind in the completely closed

* 'Recherches anatomiques et histologiques sur le Cyclostoma elegans,' pp. 49-60 (1887). 
renal organ of Ascidians of the family Molgulidæ. But in the latter animals the symbiotic Fungi belong to a group much higher than the Schizomycetes. The older writers have described and imperfectly figured foreign bodies in the kidney of the Molgulidæ, calling them confervoid filaments, gregariniform bodies, \&c., and supposing them to belong to diverse creatures*. In reality these productions must be referred to Fungi of the tribe Siphomycetes (Sorokine) and of the family Chytridinex. The parasites of the various species of Molgulidæ belong to different species, but in the same species of Ascidia wo generally find only one species of parasite in very various stages of evolution. I give these Fungi the generic name of Nephromyces. The most nearly allied genus seems to me to be Catenaria, Sorokine, the type species of which, Catenaria anguillulce, is parasitic upon Nematoda. However, in Nephromyees the sporangia are always terminal.

I have particularly studied two species of Nephromyces having as their hosts two Molgulidæ which are very common at Wimereux :1. Nephromyces Molgularum, parasitic upon Molgula socialis, Alder; and 2. Nephromyces Sorokini, a parasite of Lithonephrya eugyranda, Lac.-Duth.

Nephromyces Molgularum forms around the isolated concretions which fill the kidney of Molgula socialis a unicellular mycelium with very delieate filaments strongly felted together, the free extremities of which are terminated by spheroidal dilatations; notwithstanding their appearance, I have never seen these terminal swellings detach themselves from their support and behave like conidial spores.

This delicate, transparent mycelium produces a great number of much thicker tubes of irregularly cylindrical form, more or less contorted upon themselves, and filled with a finely granular opaque protoplasm which is strongly stained by picrocarmine. Side by side with these protoplasmic masses originate, in enormous quantity, zoosporangia of very varied forms, often bifureated at their free extremity, and in these are developed a multitude of very active zoospores of excessively small size. The formation of the zoospores is preceded by a spumous appearance of the protoplasm, such as has been indicated in various Chytridineæ, and by the formation of thicker septa separating the sporangium from the rest of the mycelium. For a long time I had only a very imperfect notion of these zoospores, and I have been able to make anything of their study only by the aid of Zeiss's excellent apochromatic objectives. The zoospores are perfectly spherical, and furnished with a pretty long but very slender flagellum; they contain a strongly refractive granule towards the origin of the flagellum. It is probable that these active bodies introduce themselves into the branchix of the young Molgulce, and penetrate by diapedesis into the renal organ, since neither by injections nor by sections has any opening been found into that organ.

* Lacaze-Duthiers, Arch. de Zool, exrér. et gén. tome iii. pl. xi. (1874). 
Towards the end of the summer the empty zoosporangia separated from the mycelium often encumber preparations; generally they present, at various parts of their wall, especially at the extremities, swellings formed by a layer of undifferentiated refractive protoplasm.

During the autumn months, in the Molgulce produced in the spring, the mycelium presents a great quantity of zygospores. These reproductive bodies, which are much larger than the zoospores, originate isolatedly, but at very closely approximated points, where several (usually four or five) filaments of the mycelium conjugate. The zygospores have a finely granulated envelope, perhaps even slightly echinulate. During the winter, at the beginning of February, these zygospores germinate by emitting two equal filaments, terminating in points and slightly divergent, which give the spore in course of evolution the form of a pair of compasses. The two branches of these compasses open more and more, and the compassstage gradually becomes converted into a fusiform stage, in which the spore is no longer visible except as a median swelling, which soon disappears completely.

Side by side with these varions forms we find all the year round pretty long tubes, wider than the mycelium from which they separate readily, and rounded at the two extremities. Upon their walls these tubes present a fine plasmatic deposit arranged in two intercrossing spirals, or perhaps disseminated around vacuoles placed end to end throughout the length of the tube. The meaning of these parts completely escapes me.

Anurella roscovitana, Lac.-Duth., cortains a Nephromyces ( $N$. roscovitanus) nearly allied to $N$. Molgularum, but nevertheless quite distinct.

The species parasitic upon Lithonephrya eugyranda, and which I name Nephromyces Sorokini, is very distinctly characterized by the form of its regularly pyriform zoosporangia with two refractive masses, one at the apex, the other at the base, at the point where the sporangium is inserted upon the mycelium. In the Lithonephryce the kidney is almost entirely filled by a single very voluminous concretion. A very limited space is left, therefore, for the symbiotic fungus, and hence the latter is much less abundant than its congeners parasitic upon the Molgulce.

The arrangements of the laboratory at Wimereux have not permitted me hitherto to make experiments upon the culture of the Fungi of the genus Nephromyces in artificial media containing guanine or urie acid. I think, however, that such cultures may be possible, and that these Fungi are useful to the Tunicates which they infest by freeing them of the excreted products, which, without them, would rapidly choke up the kidney, which is destitute of any evacuatory duct.-Comples Rendus, April 16, 1888, p. 1180. 